\title{
The role of citicoline in cognitive impairment: pharmacological characteristics, possible advantages, and doubts for an old drug with new perspectives [Corrigendum]
}

\author{
Gareri P, Castagna A, Cotroneo AM, Putignano S, De Sarro G, \\ Bruni AC. Clin Interv Aging. 2015;10:1421-1429.
}

On page 1423, Figure 2 Citicoline's metabolic pathways, please note that this figure has been modified to include: Adibhatla RM, Hatcher JF, Dempsey RJ. Effects of citicoline on phospholipid and glutathione levels in transient cerebral ischemia. Stroke. 2001;32(10):2376-2381. management system is completely online and includes a very quick and fair peer-review system, which is all easy to use. Visit http://www.dovepress. in human beings. This journal is indexed on PubMed Central, MedLine, 